\title{
Legal Provisions and Union Leader Expectations for Enforcement of Quality of Work-Life Initiatives in Nepal
}

\author{
Dr. Prakash Shrestha \\ Lecturer, Nepal Commerce Campus, Tribhuvan University, Nepal \\ Dr. Dilip Parajuli* \\ Associate Professor, Bhaktapur Multiple Campus, Tribhuvan University, Nepal \\ *E-mail of the corresponding author: dilipparajuli2020@gmail.com
}

\begin{abstract}
The purpose of this paper is to analyze the emerging views and approaches to work-life quality (QWL), legal provisions, and expectations of the union leader for the enforcement of QWL initiatives in Nepal. It reviews and describes three major labor laws such as the Labor Act, 2017, Child Labor (Prohibition and Regulation) Act, 2000, and Trade Union Act, 1992. To understand the expectations of union leaders, a questionnaire survey is administered by approaching 55 members of trade unions associated with All Nepal Federations of Trade Unions (ANTUF), General Federation of Nepalese Trade Unions (GEFONT), and Nepal Trade Union Congress (NTUC). The variables of QWL are adapted from Walton (1975). The evidence shows three approaches to QWL such as the scientific management approach, the human relations approach, and orientation to work are in practice. The results also reveal that Nepalese union leaders primarily expect adequate and fair compensation, safe and healthy working conditions, and opportunity for continuous growth and security to maintain an effective QWL situation in Nepal. Effective implementation of the QWL-related legal provisions favors a better QWL situation in Nepal. The ignorance of QWL initiatives would undoubtedly have negative consequences for Nepalese companies. The provisions in the labor laws are seemed to be enough if they are honestly implemented. Hence, effective implementation of the QWL-related legal provisions, thus, favors a better QWL situation in Nepal.
\end{abstract}

Keywords: Acts, Enforcement, Government, Legal provisions, Quality of work-life, Union leader

DOI: $10.7176 / \mathrm{JLPG} / 102-01$

Publication date:October $31^{\text {st }} 2020$

\section{Introduction}

Quality of work-life (QWL) is one of the most important aspects of managing employee relations at workplaces. It, primarily, refers to the favorable situations and work environment of employee advantage, benefit, welfare, and management attitudes towards workers at the workplace as well as employees in general. QWL is the quality of connections between workers and the entire working environment of the workplace. It is an employee's recognition of physical and psychological well-being at work. It makes jobs more challenging, satisfying, and interesting.

QWL implies distinctive implications and meaning to different people. Hackman and Suttle (1977) argue that few individuals consider it an industrial democracy or co-determination with increased employee participation in the decision-making process whereas some managers and administrators consider it an enhancement in the psychological aspects of work to improve efficiency. They further argue that unions and workers interpret QWL as a more equitable sharing of benefits, job security, sound, and congenial working conditions. QWL improves social relationships at the workplace through autonomous workgroups. It changes the entire organizational climate by humanizing work, individualizing organizations, and creating structural and managerial systems (Hackman \& Suttle, 1977).

Robbins (1989) argues that QWL is a process by which an organization responds to employee needs by developing mechanisms to allow them to share fully in making the decisions that help to design their work-life (p. 207). QWL aims to develop jobs and working conditions that are excellent for people as well as for the economic health of the organization (Dolai, 2015). This concept was created to meet the essential personal needs of the workers to work and share their organizational experiences. It offers greater opportunities for workers to take part in the organizational decision-making process.

\section{Emerging Views on QWL}

Different researchers have presented their concepts and varied approaches for improving QWL at workplaces. Table 1 provides emerging views or main premises on the QWL: 
Table 1: Different views on QWL

\begin{tabular}{|c|c|}
\hline Authors/Date & Main Premises \\
\hline Cherns (1978) & $\begin{array}{l}\text { "the bond of the structural, systems perspective of organizational behavior with } \\
\text { the interpersonal, human relations, supervisory-style perspective" }\end{array}$ \\
\hline Davis (1981) & "the favorableness or unfavorableness of the work environment for individuals" \\
\hline Bowditch \& Bouno (1982) & $\begin{array}{l}\text { "the constant stressing the interaction of personal needs with the organizational } \\
\text { and social dynamics of the working environment" }\end{array}$ \\
\hline Ellinger \& Nissen (1987) & $\begin{array}{l}\text { "the condition based on mutual respect, which supports and encourages } \\
\text { individual participation and open communication in matters that affect works, } \\
\text { business, prospects, and perception of self-worth" }\end{array}$ \\
\hline Robbins (1989) & $\begin{array}{l}\text { "responding to the employees and their needs by creating mechanisms to allow } \\
\text { them to share completely in making the decisions that design their lives at work" }\end{array}$ \\
\hline Kiernan \& Knutson (1990) & "integrating the employee's personal needs with company's role expectations" \\
\hline Jain (1991) & $\begin{array}{l}\text { "the responsive endeavors that are aimed at progressing working conditions, work } \\
\text { content and it's attendant conditional like safety, security compensation and } \\
\text { benefits can qualify as QWL activity" }\end{array}$ \\
\hline Havlovic (1991) & "the growing worker involvement and management of the work environment" \\
\hline $\begin{array}{l}\text { Sirgy, Efraty, Siegel, \& Lee } \\
(2001)\end{array}$ & $\begin{array}{l}\text { "the employee job satisfaction with a variety of wants through resources, } \\
\text { activities, and outcomes or results stemming from cooperation within the work } \\
\text { environment" }\end{array}$ \\
\hline Bateman \& Snell (2003) & "the program that creates a workplace that progress employee well-being." \\
\hline $\begin{array}{l}\text { Rose, Beh, Uli, \& Idris } \\
(2006)\end{array}$ & $\begin{array}{l}\text { "giving more focus on the arrangement of opportunities and benefits for workers } \\
\text { to make worthy contributions to their organizations" }\end{array}$ \\
\hline Langton \& Robbins (2007) & $\begin{array}{l}\text { "a mechanism by which organizations react to worker needs by developing } \\
\text { procedures to permit the employees to share completely in decision making that } \\
\text { plan their lives at work" }\end{array}$ \\
\hline Rethinam \& Ismail (2008) & $\begin{array}{l}\text { "the productivity of the work environment that supports and promotes sound } \\
\text { health and well-being, job security, work satisfaction, competency development } \\
\text { and adjust between work and non-work life of employees" }\end{array}$ \\
\hline $\begin{array}{l}\text { Teryima, Faajir, \& John } \\
(2016)\end{array}$ & $\begin{array}{l}\text { "focuses on enhancing the conditions of work to develop a supportive and healthy } \\
\text { work environment" }\end{array}$ \\
\hline $\begin{array}{l}\text { Ogbuabor \& Okoronkwo } \\
(2019)\end{array}$ & $\begin{array}{l}\text { "encompasses feelings about job content, physical work environment, pay, } \\
\text { benefits, promotions, autonomy, teamwork, participation in decision-making, } \\
\text { occupational health and safety, job security, communication, colleagues and } \\
\text { managers support and work-life balance" }\end{array}$ \\
\hline
\end{tabular}

It is assumed that the QWL is a philosophy and set of principles that hold people to be trusted, accountable, and able to make a valuable contribution to the organization (Rose, Beh, Uli and Idris, 2006). Many factors determine QWL at workplaces (Walton, 1975; Kiernan and Marrone, 1997). In this regard, this paper aims to analyze the emerging views and approaches to work-life quality (QWL), legal provisions, and expectations of the union leader for the enforcement of QWL initiatives in Nepal.

\section{Research Methods}

This research aims to review and examine the concept and approaches to QWL. In the first part, it reviews and describes scholarly papers to present the approaches regarding QWL. In the next part, it reviews and describes three major labor laws- Labor Act, 2017 (Ministry of Law, Justice and Parliamentary Affairs, 2017); Child Labor (Prohibition and Regulation) Act, 2000 (Ministry of Law and Justice, 2000), and Trade Union Act, 1992 (Ministry of Law and Justice, 1992). It also presents the major QWL-related provisions and mechanisms to implement these provisions.

In the final part, to understand the expectations of union leaders, a questionnaire survey is administered by approaching 55 members of trade unions associated with All Nepal Federations of Trade Unions (ANTUF), General Federation of Nepalese Trade Unions (GEFONT), and Nepal Trade Union Congress (NTUC). The variables of QWL are adapted from Walton (1975) that include adequate and fair compensation, safe and healthy working conditions, immediate opportunity to use and develop human capacities, an opportunity for continuous growth and security, social integration in the work organization, constitutionalism in the work organization, work and total life space, and social relevance of work life. Each statement is scored on a 5-point scale ranging from "strongly disagree (1 point)" and "strongly agree (5 points)". The reliability test of each variable is presented in Table 2. 


\begin{tabular}{|c|l|c|}
\hline S. no. & QWL variables & Reliability \\
\hline 1. & Adequate and fair compensation & 0.89 \\
\hline 2. & Safe and healthy working conditions & 0.78 \\
\hline 3. & Immediate opportunity to use and develop human capacities & 0.81 \\
\hline 4. & Opportunity for continuous growth and security & 0.75 \\
\hline 5. & Social integration in the work organization & 0.79 \\
\hline 6. & Constitutionalism in the work organization & 0.83 \\
\hline 7. & Work and total life space & 0.91 \\
\hline 8. & Social relevance of work life & 0.85 \\
\hline
\end{tabular}

Reliability is measured with Cronbach's Alpha value. The Alpha values are greater than the claim of Sekaran (2006). Therefore, the instruments used to measure each variable in this study are reliable enough and provides useful results.

\section{Results and Discussion}

This segment presents results and research findings. This section begins with the approaches regarding QWL. The next part presents legal provisions for enforcement of quality of work-life initiatives. Finally, it presents union leader expectations about the QWL situation at the Nepalese workplaces.

\subsection{The Approaches regarding QWL}

Many previous studies (Krahn and Lowe, 1998; Crompton and Harris, 1998; Gallie, 1990; Rose, 1994) have noticed three approaches concerning QWL. These approaches are presented below:

- The scientific management approach: This approach of QWL was practiced in the era of scientific management. According to this approach, QWL was based on extrinsic traits of jobs: salaries, safety and hygiene, and other tangible benefits of the workplace.

- The human relations approach: This approach stressed that, while extrinsic rewards are important for improving QWL. The human relations approach focused on intrinsic traits of the job that include autonomy, challenges, and task contents, which are key predictors of productivity and efficiency.

- Orientation to work: This approach of QWL has suggested that a focus on extrinsic or intrinsic reward is contingent on the person.

However, the success of the QWL initiatives depends on transparency and trust, information management, organizational culture, management, and employee partnerships (Casio, 1992). Equally important is the responsibility of improving QWL, it should be shared jointly through legislation by employees, owners, union leaders, and governments (Suttle, 1977). These stakeholders' roles are most important in securing the employers' and employees' rights and interests (Adhikari and Gautam, 2010).

\subsection{Legal provisions for enforcement of quality of work-life initiatives}

The Government role is vital for promoting the QWL situation in any country. In the business field, with the increasing impact of liberalization and deregulation of the economy, organizations in developed and developing countries are demanding more autonomy in labor-related decisions. In this situation, labor laws should address the provisions and mechanisms for implementing the QWL program. Therefore, the legislative role is indispensable for maintaining and promoting the QWL program in the country.

The Government of Nepal (GoN) has constituted some labor legislation for protecting the rights and interests of different employers and employees in Nepal. This study attempted to review the current labor laws to examine how far these laws' provisions have remained successful in implementing QWL programs in the country in the past. At the national level, the three major labor acts prescribing QWL dimensions are Labor Act, 2017 (previously, Labor Act, 1992), Trade Union Act, 1992, and Child Labor (Prohibition and Regulation) Act, 2000. These three acts are reviewed and discussed below:

4.2.1 The Labor Act, 2017

The Labor Act, 1992 (as amended in 1998) was replaced by the Labor Act, 2017, which outlined QWL-related provisions for the rights, interests, equipment, and safety of workers operating in businesses in different industries. The Labor Act 2017 applies to all organizations or companies irrespective of the number of workers. The major QWL-related provisions and implementation mechanisms of this Act are presented in Table 3. 
Table 3: Labor Act, 2017 and QWL-related provisions and implementation mechanisms QWL-related provisions

- Hiring

- Working Hours and Probation period

- Leave \& Holidays

- Terminal Benefits (Provident Fund, Gratuity, Leave Encashment)

- Other Benefits (Housing Fund, Festival Expenses, Disability Compensation, Compensation against Injury, Death Compensation, Medical Insurance, Accident Insurance)

- Safety and Health Arrangement

- Special provision for women

- Disciplinary Action

- Termination of Employment

- Flexibility in Retrenchment

- Collective Bargaining

- Sanctions for the violation of the provision Social Security

Source: Ministry of Law, Justice and Parliamentary Affairs (2017)

This Act applies to businesses, private firms, partnership firms, cooperatives, organizations, or other organizations that are in operation or that are established, incorporated, registered, or formed under current lawsirrespective of their goal of earning a profit or not. It also applies to individuals even if they have engaged in different types of jobs including domestic workers as a single person. It also applies to an organization or company registered in a foreign country but involved in business promotion, sale of its products and services, or other works in Nepal.

This Act has given the adaptability within the modes of contracting as per the necessities of the substance such as regular employment, work-based employment (for completion of different category of work or rendering different service). Similarly, the time-bound employment category is determined, provisions made for casual work for seven or fewer days in a month, and part-time employment for 35 or fewer hours in a week. The Act addresses that all employers enter into an employment agreement or give an appointment letter to all its employees and workers.

Concerning the safety and health agreement, it states that all organizations with more than 20 employees have to form the Safety and Health Committee. The employer shall be jailed for up to 2 years if any worker dies or is injured in the absence of safety and health arrangements. The severity of this provision in the Act is quite predominant.

Under this Act, overtime is payable at the price of one-and-a-half times the remuneration of the worker. The Act specifies the period within which employees compensated, e.g. regular employees-payment period is not to exceed one month. Mainly, it has stated the probation period of six months from the date of employment.

This Act has also specified unique arrangements and provisions for women employees. Women employees are eligible for an additional public holiday on International Women's Day, transportation services to their location of residence if their working hours begin or end before sunrise or after sunset, 14-week maternity leave with pay for 60 days of maternity leave. The employer is required to create provisions in the event of a job during pregnancy so that the work delegated to the pregnant worker does not adversely affect her health. The provision of this Act also provides for employee leave allowances such as weekly leave (one day per week), public holidays (13 days per year, 14 days per year for females) and mourning leave (13 days), and complete pay sick leave for 12 days. This Act also arranges the gratuity, the provident fund, and the new social security fund. This Act also provides leave for festivals and insurance for medical and accidental expenses. The Act allows employees for a peaceful strike, with a notice of seven days on certain conditions such as failure to arbitrate compulsorily, failure to constitute an arbitrary tribunal, failure to employees to accept the arbitrary award after its decision, or even if the employer challenges the arbitrary award. If the strike legally called off, the employees are qualified to receive half of their pay. They are not eligible for receiving their remuneration if they conducted illegally.

There is also a provision of collective bargaining committee agreement and dispute resolution. Each organization with ten or more employees must establish a collective bargaining committee. The committee bargains with all or at least $60 \%$ of the trade union representatives. The manager or employees at the management level, however, cannot be a representative to a collective bargaining committee or a representative of the collective bargaining.

4.2.2 Child Labor (Prohibition and Regulation) Act, 2000

The Child Labor (Prohibition and Regulation) Act, 2000 regulates and prohibits the use of children under the age of 14. This act provides for the following clauses:

- Children under the age of 16 are described as children.

- Children must not be employed by in specified dangerous and hazardous works such as tourism-oriented 
jobs, workshop/lab/cold storage, public transport and construction, tobacco-based work, carpet dyeing, beer and liquor, plastic, glass, insecticides, matches, etc.

- The approved government agency should provide permission for the employment of a child.

- $\quad$ Child labor shall not be work between 6 p.m. and 6 a.m.

- Child labor shall not exceed 6 hours a day or 36 hours a week

- The Labor Department has provided authority to inspect organizations that are employing child workers.

The major QWL-related provisions and implementation mechanisms of the Child Labor (Prohibition and Regulation) Act are presented in Table 4.

Table 4: Child Labor (Prohibition and Regulation) Act, 2000 and QWL-related provisions and implementation mechanisms

\begin{tabular}{|c|c|}
\hline QWL-related provisions & Implementation mechanisms \\
\hline $\begin{array}{l}\text { - Prohibition on engaging children in employment } \\
\text { - } \text { Provisions for engaging children in works } \\
\text { - } \text { of child labor. } \\
\text { - } \text { Qualification certificate to be obtained. } \\
\text { - Remune to engage in work } \\
\text { - Health and safety measures }\end{array}$ & $\begin{array}{l}\text { - Inspection, direction, and action from the labor office } \\
\text { and government } \\
\text { - Child labor prohibition committee and fund } \\
\text { - Labor office approvals } \\
\text { - Peputation of child labor inspector and action } \\
\text { - Complaints and limitations }\end{array}$ \\
\hline
\end{tabular}

Under this Act, a Child Labor Prevention Committee shall be established by the Government of Nepal to provide health, safety, education, and vocational training to a child operating in a business. The government will establish a Child Labor Prevention Fund for child labor prevention. The Government shall provide the required instructions for the implementation of the goals of this Act to executives, trade unions, and child welfare organizations. Labor Office also has the authority to punish if a plant fails to comply with the laws and regulations.

With the QWL-related provisions in these labor acts, the GoN is actively playing a guardian role to protect the interests of workers and employees working in Nepal. The responsibility of employers or companies is to obey rules and regulations. These employers or companies have to follow the mechanism to ensure a better QWL environment at the organizational level in the country.

4.2.3 Trade Union Act, 1992

This Act constituted to protect the rights of the trade union members. Workers can form an enterprise-level trade union to protect and promote their occupational rights in any enterprise. The major QWL-related provisions and implementation mechanisms of this Act are presented in Table 5.

According to this Act, the trade union associations and federations have to involve in collective bargaining on behalf of the enterprise-level unions. These unions have to let the workers follow the decision made by the enterprise level authorized trade union. The authorized trade unions shall not go on strike and refuse to continue working in enterprise or do such action that may assist it in any manner without completing the process mentioned in this Act.

Table 5: Trade Union Act, 1992 and QWL-related provisions and implementation mechanisms

\begin{tabular}{|c|c|}
\hline QWL-related provisions & Implementation mechanisms \\
\hline $\begin{array}{l}\text { - Forming enterprise-level trade union } \\
\text { - Involvement in collective bargaining } \\
\text { - Working committee } \\
\text { - Presentation of claim } \\
\text { - Restricting activities of the trade union that create an } \\
\text { - } \text { uncontrollable situation } \\
\text { - Maintaining industrial relation, peace, and harmony }\end{array}$ & $\begin{array}{l}\text { - Appointment, functions, duties, and power of } \\
\text { the Registrar } \\
\text { - Labor courts } \\
\text { - Operation, management, and recognition of } \\
\text { trade union } \\
\text { - Special power of GoN (government } \\
\text { directions or orders) }\end{array}$ \\
\hline
\end{tabular}

This Act also mentions that the GoN shall appoint Registrars as necessary for the registration of a trade union under this Act. The GoN can give directions or orders restricting any activity of trade union seem to create an uncontrollable situation that is disturbing the industrial relation, peace, and harmony or to go against the development of the economy of the country.

\subsection{QWL and Union Leader Expectations}

Union leaders are interested in assessing the QWL situation in Nepal. They expect a sound QWL situation at the workplace. The results of a recent survey are presented in Table 6 . 
Table 6: QWL and Union Leader Expectations

\begin{tabular}{|c|l|c|c|}
\hline S. no. & QWL variables & Mean & SD \\
\hline 1. & Adequate and fair compensation & 3.84 & 0.81 \\
\hline 2. & Safe and healthy working conditions & 3.54 & 0.78 \\
\hline 3. & Immediate opportunity to use and develop human capacities & 3.12 & 0.92 \\
\hline 4. & Opportunity for continuous growth and security & 3.24 & 0.76 \\
\hline 5. & Social integration in the work organization & 3.23 & 0.86 \\
\hline 6. & Constitutionalism in the work organization & 3.19 & 0.78 \\
\hline 7. & Work and total life space & 2.91 & 0.65 \\
\hline 8. & Social relevance of work life & 3.05 & 0.51 \\
\hline \multicolumn{2}{l}{ Note: $n=55$} & & \\
\hline
\end{tabular}

According to Table 6, the first three highest mean scores are adequate and fair compensation, safe and healthy working conditions, and opportunity for continuous growth and security that are expected by Nepalese union leaders to maintain an effective QWL situation in Nepal. Moreover, there are also expected some other dimensions of QWL such as social integration in the work organization, constitutionalism in the work organization, immediate opportunity to use and develop human capacities, and social relevance of work life. These all indicate that such factors are efficient and are imperative for ensuring effective QWL initiatives at Nepalese workplaces.

\section{Conclusions}

Like governments of developed and developing countries, GoN is also adapting many measures to maintain and improve the QWL situation. The GoN has been playing various roles in implementing provisions relating to QWL. It has enacted numerous laws, rules, and regulations relating to labor. It has also attempted to ensure that the QWL mechanism is properly developed and that organizations are working according to the rules and regulations. Since the government is still the economy's largest employer, Adhikari (2005) focuses on the government itself sitting on the negotiating table to negotiate with trade unions to reach an agreement on various human resources and labor-related issues. While the Nepalese economy is open and the process of deregulation is underway, there are still a lot of roles to play from the government side to safeguard the interests of workers and employees. Similarly, the role of employers and trade unions is also crucial in keeping a sound QWL environment in Nepal. Adhikari (2005) mentions that although the government has passed various acts in the past, it is not found to be very effective at the organizational level for their compliance. Provisions in the three separate acts mentioned above appear to be enough if they are applied honestly. Labor laws protect the rights and interests of both the company and its employees (Shrestha, 2016). Adhikari and Gautam (2010) also revealed that the government and employers have failed to follow and implement appropriate labor law mechanisms. There are several lapses in Nepalese businesses when applying labor laws. In such a situation, maintaining QWL at the organizational level is genuinely difficult.

In conclusion, ignorance of QWL initiatives will certainly have detrimental impacts on Nepalese companies and workers. Effective implementation of the QWL-related legal provisions, thus, favors a better QWL situation in Nepal. With regard to the expectations of the leaders of the trade unions, these leaders expect businesses to have to create a reasonable system for enforcing labor laws. It is also required that there should be frequent monitoring by the government. A previous study by Adhikari and Gautam (2010) also concluded that the leaders of the union are also waiting for the government to create a mechanism through labor actions to ensure the rights of workers. Therefore, the government has to introduce the QWL initiatives to achieve success, and they agree that the government also has to play a leading role in ensuring sound industrial relations in Nepal.

\section{References}

Adhikari, D.R. (2005). Labor legislation and quality of work life in Nepal. International Society for Labor and Social Security Law, 8th Asian Regional Congress, October 31-November 3, Taipei, pp. 167-192.

Adhikari, D.R., \& Gautam, D.K. (2010). Labor legislations for improving quality of work life in Nepal. International Journal of Law and Management, 52(1), 40-53.

Bateman, T. S., \& Snell, S. A. (2003). Management building competitive advantage. Boston, MA: Irwin McGrawHill.

Bowditch, J.R., \& Bouno, A.E (1982). Quality of work life assessment: A survey-based approach. Boston: Auburn House.

Casio, W.F. (1992). Managing human resources: Productivity, quality of worklife, profits. New York: McGrawHill.

Cherns A. (1978). Perspectives on the quality of working life. International Studies of Management and Organization, 8(1), 38-58.

Crompton, R., \& Harris, F. (1998). Explaining women's employment patterns: orientations to work revisited. British Journal of Sociology, 49(1), 118-36. 
Davis, K. (1981). Human behaviour at work. New Delhi: Tata McGraw Hill publishing company Ltd.

Dolai, D. (2015). Quality of work life initiatives: examples from Indian companies. Global Journal for Research Analysis, 4(7), 287- 288.

Ellinger, C., \& Nissan, B. (1987). A case study of a failed program: Implications for labor education. Labor Studies Journal, 11(3), 195-219.

Gallie, D. (1990). John Goldthorpe's critique of liberal theories of industrialism. In Clark, M. (Ed.). John H. Goldthorpe - Consensus and Controversy. The Falmer Press, London.

Hackman, J.R., \& Suttle, J.L. (Eds.) (1977). Improving life at work: Behavioral science approaches to organizational change. Goodyear, Santa Monica, CA.

Havlovic, S.J. (1991). Quality of work life and human resource outcomes. Industrial Relations, 30(1), 469-479.

Jain, S. (1991). Quality of work life. New Delhi: Deep \& Deep publications, p. 17.

Kiernan, W. E., \& Marrone, J. (1997). Quality of work life for persons with disabilities: Emphasis on the employees. In R. L. Schalock and Gary N. Siperstein (Eds.). Quality of life: Application to persons with disabilities (pp. 63-77). Washington, DC: American Association of Mental Retardation.

Kiernan, W.E., \& Knutson, K. (1990). Quality of work life. In R. Schalock (Ed.). Quality of life: Perspectives and issues (pp. 101-114). Washington, DC: American Association of Mental Retardation.

Krahn, H., \& Lowe, G. (1998). Work, industry and Canadian society. Nelson, Toronto, pp. 381-429.

Langton, N., \& Robbins, S.P. (2007). Organizational behaviour: Concepts, controversies and applications. Toronto, Canada: Pearson Education.

Ministry of Law and Justice (1992). Trade union act. Ministry of Law and Justice, Kathmandu, Nepal.

Ministry of Law and Justice (2000). Child labor act. Ministry of Law and Justice, Kathmandu, Nepal.

Ministry of Law, Justice and Parliamentary Affairs (2017). Labor act. Ministry of Law, Justice and Parliamentary Affairs, Kathmandu, Nepal.

Ogbuabor, D.C., \& Okoronkwo, I.L. (2019). The influence of quality of work life on motivation and retention of local government tuberculosis control programme supervisors in South-eastern Nigeria. PLoS ONE, 14(7): e0220292. https://doi.org/10.1371/journal.pone.0220292

Rethinam, G. S., \& Ismail, M. (2008). Constructs of QWL: A perspective in Information Technology Professionals. European Journal of Social Sciences, 7(1), 58-69.

Robbins, S.P. (1989), Organizational behavior: Concepts, controversies, and applications, Englewood Cliffs, NJ: Prentice-Hall.

Rose, M. (1994). Job satisfaction, job skills, and personal skills. In Penn, R., Rose, M. and Rubery, J. (Eds.). Skills and Occupational Change. Oxford: Oxford University Press.

Rose, R.C., Beh, L, Uli, J., \& Idris, K. (2006). An analysis of quality of work life (QWL) and career-related variables. American Journal of Applied Sciences, 3(12), 2151-2159.

Sekaran, U. (2006). Research methods for business: A skill-building approach. New York: John Wiley and Sons, Inc.

Shrestha, P. (2016). Organizational justice and employee work outcomes in service sector of Nepal. Unpublished $\mathrm{Ph}$.D. dissertation submitted to the Faculty of Management, Tribhuvan University, Kathmandu, Nepal.

Sirgy, M. J., Efraty, D., Siegel, P., \& Lee, D. (2001). A new measure of quality of work life (QWL) based on need satisfaction and spillover theories. Social Indicators Research, 55(1), 241-302.

Suttle, J.L. (1977). Improving life at work: problems and prospects. In Hackman, J.R., \&Suttle, J.L. (Eds.). Improving Life at Work: Behavioral Science Approach to Organizational Change, Goodyear Publishing Company, Santa Monica, CA, pp. 1-29.

Teryima, S.J., Faajir, A., \& John, E. (2016). Examining employee quality of work life (QWL) as a determinant of managerial effectiveness in business organizations: a study of Nigeria Breweries plc, Lagos. The Business and Management Review, 7(3), 268-281.

Walton, R. E. (1975). Criteria for quality of work life. In L. E. Davis, \& A. B. Cherns (Eds.). Quality of working life: problems, projects, and the state of the art (Vol. 1, Chap. 5, pp. 91-104). New York: The Free Press, Collier-Macmillan. 